\title{
PRODUKSI BAKTERIOSIN OLEH Lactobacillus plantarum DJ3 DAN APLIKASINYA SEBAGAI PENGAWET DAGING
}

\author{
Liliek Hariani \\ Jurusan Biologi, Fakultas Sains dan Teknologi \\ Universitas Islam Negeri (UIN) Maulana Malik Ibrahim Malang
}

\begin{abstract}
Lactic acid bacteria $(L A B)$ are able to inhibit other bacteria by producing protein, named as bacteriocin. Bacteriocin which produced by LAB is useful to inhibit pathogenic bacteria that harmful to human health or even makes food spoil. Bacteriocin is effective as antibacterial agent against pathogenic bacteria. Crude Extract of bacteriocin that produced by Lactobacillus plantarum DJ3 is able to inhibits the growth of E. Coli $(4 \mathrm{~mm})$ and $S$. aureus $(5.33 \mathrm{~mm})$. Application of bacteriocin in beef show that it able to inhibita the growth of bacteria. The amount of bacteria in beef that stored in 8 hours with bacteriocin addition are $1,3 \times 10^{8}$ $\mathrm{CFU} / \mathrm{g}$, and $3.7 \mathrm{X} 10^{8} \mathrm{CFU} / \mathrm{g}$ without bacteriocin addition. While the amount of bacteria in beef that stored in 12 hours with bacteriocin addition are $2.0 \times 10^{9}$ CFU/g and $1.5 \times 10^{11}$ without bacteriocin addition.
\end{abstract}

Key words : Bacteriocin, Lactobacillus plantarum DJ3, meat preservation

\section{PENDAHULUAN}

Penggunaan agensia pengawet kimia seperti formalin pada makanan walaupun di satu sisi dapat memperpanjang umur simpan makanan, namun dilain pihak keamanannya masih dipertanyakan. Residu bahan kimia yang tertinggal di dalam tubuh dapat memicu timbulnya berbagai macam penyakit diantaranya kanker (Nugroho dan Rahayu, 2003). Untuk mengatasi hal tersebut maka pemanfaatan bahan pengawet alami (biopreservasi) sangat potensial untuk diaplikasikan dalam pengawetan pangan (Ammor,et al., 2006) karena dapat mengontrol pertumbuhan bakteri patogen secara alami dan aman (Mataragas, et al., 2003).

Salah satu agen biopreservatif yang sangat potensial digunakan sebagai pengawet pangan adalah bakteriosin. Karena bakteriosin mampu mencegah pembusukan pangan dengan menghambat pertumbuhan bakteri patogen. Bakteriosin mampu diproduksi oleh kelompok Bakteri Asam Laktat (BAL). Beberapa galur Bakteri Asam Laktat (BAL) dapat menghasilkan senyawa protein yang disebut bakteriosin, dan bersifat bakterisidal terhadap bakteri gram positif dan gram negatif (Tahara et al., 1996). Bakteriosin dapat diproduksi oleh Lactococcus, Lactobacillus dan
Pediococcusyang berasal dari berbagai bahan makanan, misalnya nisin diproduksi oleh Lactococcus lactis, pediosin AcH dihasilkan Pediococcus acidilactic. Beberapa kelebihan bakteriosin sehingga potensial digunakan sebagai biopreservatif yaitu: (i) bukan bahan toksik dan mudah mengalami degradasi oleh enzim proteolitik karena merupakan senyawa protein; (ii) tidak membahayakan mikroflora usus karena mudah dicerna oleh enzim saluran pencernaan; (iii) dapat mengurangi penggunaan bahan kimia sebagai pengawet pangan; (iv) penggunaannya fleksibel; dan (v) stabil terhadap $\mathrm{pH}$ dan suhu yang cukup luas sehingga tahan terhadap proses pengolahan yang melibatkan asam dan basa, serta kondisi panas dan dingin (Cleveland et al., 2001).

Pemakaian bakteriosin komersial sebagai biopreservatif sudah dilakukan di beberapa negara dan diaplikasikan pada beberapa jenis makanan.Di Indonesia salah satu yang telah mencoba penggunaan bakteriosin sebagai pengawet alami adalah Balai Besar Penelitian dan Pengembangan Pascapanen Pertanian untuk pengawetan daging ayam dan hasil aplikasinya menunjukkan bahwa daging ayam dapat dipertahankan kesegarannya selama 18 jam, padahal daging ayam tanpa pengawet biasanya 
bertahan segar selama 10 jam (bila penanganannya bersih) dan 6 jam (bila penanganannya tidak bersih). Bakteri patogen yang banyak dijumpai pada daging mentah antara lain Escherichia coli, Salmonella sp.,dan Listeria monocytogenes (Usmiati, S., dan Marwati, T., 2007).Bakteriosin sebagai agen biopreservatif sangat potensial digunakan untuk mengendalikan beberapa bakteri patogen pada daging, tetapi secara komersial ketersediaanya masih sedikit dan harganya sangat mahal, padahalkoleksi bakteri asam laktat (BAL) di Indonesia tersedia cukup banyak

Berdasarkan hal tersebut penelitian ini bertujuan untuk mengaplikasikan bakteriosin yang dihasilkan oleh Lactobacillus sp.pada daging sapi. Sebagaimana diketahui bahwa daging sapi berperanan cukup besar dalam konteks ketahanan pangan nasional karena merupakan salah satu komoditas sumber protein hewani yang penting untuk kesehatan dan pertumbuhan. Kesehatan daging merupakan bagian yang penting bagi keamanan pangan dan selalu menjadi pokok permasalahan yang mendapatkan perhatian khusus dalam penyediaan daging untuk konsumen. Daging yang disimpan pada suhu kamar pada waktu tertentu akan mengalami kerusakan. Hal ini karena daging merupakan bahan pangan yang bergizi tinggi dan media yang baik untuk pertumbuhan mikroba. Kerusakan daging oleh mikroba mengakibatkan penurunan mutu daging. Jumlah dan jenis mikroba yang mencemari permukaan daging ditentukan oleh penanganan sebelum penyembelihan ternak dan tingkat pengendalian hiegines dan sistem sanitasi yang baik selama penanganan hingga dikonsumsi. Besarnya kontaminasi mikroba pada daging menentukan kualitas dan masa simpan daging. Untuk menghindari kerusakan, daging perlu diawetkan dengan memperhatikan persyaratan keamanan pangan (Usmiati, 2010).

Penggunaan bakteriosin untuk pengawet alami perlu mempertimbangkan pula sifat-sifat kestabilan bakteriosin tersebut, karena di dalam pengolahan makanan sering melibatkan proses suhu baik tinggi maupun suhu rendah. Mengingat besarnya manfaat bakteriosin untuk keamanan pangan maka penelitian tentang produksi bakteriosin oleh BAL Lactobacillus plantarumDJ3 serta aplikasinya untuk pengawetan daging sapi.
Tujuan PenelitianTujuan dari penelitian ini adalah untuk mengetahui kemampuanLactobacillus plantarumDJ3 dalam memproduksi bakteriosin dan lama penyimpanan daging yang diberi pengawet bakteriosin

\section{METODE PENELITIAN}

\section{Rancangan Penelitian}

Penelitian dilakukan secara diskriptif yang terdiri dari 2 tahap dan setiap tahap diulang 3 (tiga) kali : Tahap I : Produksi bakteriosin oleh Lactobacillus plantarum. Tahap II : Lama penyimpanan daging $(\mathrm{P})$ yang diberi pengawet bakteriosin, P1: 8 jam dan P2: 12 jam

\section{Pelaksanaan Penelitian \\ Pembuatan Media}

Media MRS agar dibuat dengan melarutkan $6.28 \mathrm{~g}$ dalam $100 \mathrm{ml}$, media MRSbroth dibuat dengan melarutkan $5.22 \mathrm{~g}$ dalam $100 \mathrm{ml}$, media Nutrient Agar dibuat dengan melarutkan $2.3 \mathrm{~g}$ dalam $100 \mathrm{ml}$ dan media Nutrient Broth dibuat dengan melarutkan $0.9 \mathrm{~g}$ dalam $100 \mathrm{ml}$ Semua bahan dipanaskan sampai mendidih sambil diaduk hingga larut, kemudian media tersebut dimasukkan ke dalam enlenmeyer dan ditutup kapas, kemudian disterilisasi dalam autoklaf menggunakan suhu $121{ }^{\circ} \mathrm{C}$ dan tekanan $1 \mathrm{~atm}$ selama 15 menit.

\section{Peremajaan Bakteri}

Peremajaan bakteri dilakukan dengan mengambil 2 ose bakteri Lactobacillus plantarum DJ3 dan digoreskan pada media MRSA miring. Sedangkan untuk bakteri patogen yaitu Escherichia coli dan Staphylococcus aureus digoreskan pada media NA miring.

\section{Pembuatan Kurva Pertumbuhan Bakteri Lactobacillus plantarum DJ3}

Pembuatan kurva pertumbuhan dilakukan dengan cara menginokulasikan sebanyak 2 ose masing-masing bakteri Lactobacillus plantarum DJ3 hasil peremajaan ke dalam $200 \mathrm{~mL}$ media MRS broth, kemudian diinkubasi pada shakerincubator dengan kecepatan $100 \mathrm{rpm}$ pada suhu $30^{\circ} \mathrm{C}$ selama 24 jam dan setiap 3 jam sekali diambil $4 \mathrm{ml}$ untuk diukur kekeruhannya (OD) pada panjang gelombang $600 \mathrm{~nm}$. Kurva pertumbuhan dilakukan sampai fase logaritmik. 


\section{Pembuatan Inokulum (Kultur Aktif) Lactobacillus sp.}

Pembuatan inokulum dilakukan dengan cara menginokulasikan sebanyak 2 ose masing-masing hasil peremajaan bakteri Lactobacillus plantarum DJ3 ke dalam $25 \mathrm{ml}$ media MRS broth kemudian diinkubasi pada shakerincubator dengan suhu $30^{\circ} \mathrm{C}$ dan kecepatan $100 \mathrm{rpm}$ sampai fase logaritmik.

\section{Produksi Bakteriosin oleh Lactobacillus plantarum DJ3 (Razak, dkk. 2009)}

Inokulum L. plantarum DJ3 diinokulasi sebanyak $5 \mathrm{ml}$ ke dalam $45 \mathrm{ml}$ media MRS broth yang telah ditambahkan yeast extract $2 \%$ (b/v) dan diinkubasi pada shakerincubator dengan suhu $30^{\circ} \mathrm{C}$ dan kecepatan $100 \mathrm{rpm}$ selama 24 jam sehingga $\mathrm{pH}$ media menunjukkan sekitar 4. Filtrat hasil fermentasi dipisahkan dari endapan selnya dengan disentrifugasi pada $5000 \mathrm{rpm}, 4^{0} \mathrm{C}$ selama 30 menit. dan selanjutnya filtrat bebas sel dinetralkan dengan $\mathrm{NaOH}$ 1N sampai $\mathrm{pH} 7$. Filtrat hasil fermentasi tersebut merupakan ekstrak kasar bakteriosin yang akan dipakai untuk penelitian berikutnya.

\section{Uji Lama Penyimpanan Daging yang Diberi Pengawet Bakteriosin}

Uji ini dilakukan dengan membuat potongan daging sapi segar 10 gram dan merendamnya selama 30 menit dalam $10 \mathrm{ml}$ larutan bakteriosin, ditiriskan untuk mengeluarkan sisa filtrat selama 30 menit dan dikemas rapat dalam cawan petri, kemudian disimpan pada suhu ruang selama 12 jam. Pada jam ke 8 dan 12 dihitung jumlah mikroba kontaminan yang tumbuh pada daging dengan Total Plate Count (TPC).

\section{Uji Akivitas Antibakteri dari Baktriosin}

Uji penghambatan bakteriosinterhadap bakteri patogen yang digunakan dalam penelitian ini adalah Escherichia coli dan Staphylococcus aureus. Pemilihan bakteri ini mewakili bakteri Gram positif dan Gram negatif serta mewakili keberadaan bakteri patogen pada daging. Prosedur pengujiannya dilakukan dengan metode difusi cakram menurut Schillinger dan Lucke (1989) yaitu sebagai berikut:

1. Satu ose kultur bakteri uji (E. coli dan $S$. aureus) masing-masing diinokulasikan kedalam media NB (Nutrient Broth) $10 \mathrm{ml}$ dan diinkubasi pada suhu $30^{\circ} \mathrm{C}$ selama 18 jam. Masing-masing bakteri uji diinokulasikan sebanyak $25 \mu \mathrm{l}$ kedalam NA (Nutrient Agar) secara pour plate dan dibiarkan mengeras,

2. Media NA yang telah mengeras kemudian dibuat sumuran dengan alat bor yang steril di bagian tengah cawan petri,

3. Kertas cakram dengan diameter $6 \mathrm{~mm}$ direndam dalam filtrat bakteriosin selama 30 menit, kemudian diletakkan di atas media NA yang berisi bakteri uji.

4. Diinkubasi pada $30^{\circ} \mathrm{C}$ selama 24 jam,

5. Diameter zona bening yang terbentuk disekitar kertas cakram diukur sebagai zona penghambatan bakteriosin terhadap bakteri uji (bakteri patogen).

\section{Analisis Data}

Datadiolah mengggunakan metode deskriptif. Data hasil penelitian disusun dalam tabel-tabel, diklasifikasikan sehingga merupakan suatu susunan urutan data dan dimuat dalam grafik untuk kemudian diinterpretasikan sesuai dengan hasil pengamatan yang ada.

\section{HASIL DAN PEMBAHASAN}

\section{Konfirmasi Pewarnaan Gram dan Uji Katalase}

Konfirmasi pewarnaan gram dan uji katalase dilakukan untuk melihat kemurnian BAL yaitu L.plantarum DJ3 yang akan digunakan untuk penelitian ini. Hasil pewarnaan Gram menunjukkan bahwa L.plantarum DJ3adalah Gram positif dengan bentuk sel batang. Pewarnaan gram merupakan penentuan karakter isolat berdasarkan perbedaan struktur dinding sel bakteri gram positif dan negatif. Lapisan peptidoglikan yang terdapat pada dinding sel bakteri gram positif lebih tebal jika dibandingkan dengan bakteri gram negatif.Menurut Brooks et al., (2005), bakteri gram positif memiliki unsur khusus yaitu teichoic sebanyak 50\% dari berat kering dinding sel. Unsur ini memiliki fungsi untuk menjaga transportasi ion, integritas dinding sel, penggantian choline oleh ethanolamine sehingga resisten terhadap autolisis dan menjaga permeabilitas eksternal. Hasil pewarnaan gram seperti pada Gambar 1. 


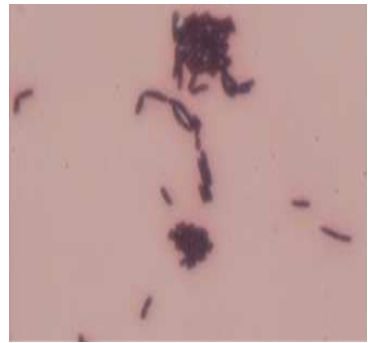

Gambar 1. Hasil Pewarnaan Gram $L$. plantarum DJ3

Hasil uji katalase menunjukkan L.plantarum DJ3 adalah katalase negatif. Uji katalase yang dilakukan pada isolat untuk mengetahui kemampuannya dalam menghasilkan enzim katalase serta toleransi isolat terhadap oksigen. Enzim katalase merupakan enzim yang mampu mengkatalis konversi hidrogen peroksida $\left(\mathrm{H}_{2} \mathrm{O}_{2}\right)$ yang toksik bagi sel menjadi air $\left(\mathrm{H}_{2} \mathrm{O}\right)$ dan oksigen. BAL merupakan kelompok bakteri yang tidak memiliki enzim katalase, tetapi memiliki enzim peroksidase untuk mengubah $\mathrm{H}_{2} \mathrm{O}_{2}$ yang bersifat toksik menjadi $\mathrm{H}_{2} \mathrm{O}$. Berbeda dengan enzim katalase yang secara langsung mengkatalisasi $\mathrm{H}_{2} \mathrm{O}_{2}$ menjadi $\mathrm{H}_{2} \mathrm{O}$ dan $\mathrm{O}_{2}$, enzim peroksidase membutuhkan reduktan seperti NADH untuk mengkatalisasi $\mathrm{H}_{2} \mathrm{O}_{2}$ menjadi $\mathrm{H}_{2} \mathrm{O}$. Persamaan reaksi kimia yang dihasilkan oleh katalisasi enzim peroksidase terhadap $\mathrm{H}_{2} \mathrm{O}_{2}$ :

$\mathrm{H}_{2} \mathrm{O}_{2}+\mathrm{NADH}+\mathrm{H}^{+} \rightarrow \quad 2 \mathrm{H}_{2} \mathrm{O}+\mathrm{O}_{2}$ (Brooks, dkk, 2005; Garbutt, 1997)

Menurut Bergey's (1994), ciri-ciri dari genus Lactobacillus adalah berbentuk batang, Gram positif, facultative anaerob, dengan ciri koloni ukuran 2-5 mm, convex, entire, keruh dan tanpa pigmen. Sehingga uji konfirmasi dan kemurnian terhadap L.plantarum DJ3yang digunakan dalam penelitian ini adalah sudah benar. L.plantarum yang digunakan dalam penelitian ini merupakan hasil isolasi dari usus itik petelur pada penelitian sebelumnya dan telah diidentifikasi sampai tingkat spesies menggunakan kit API $50 \mathrm{CH}$ (Muwakhid dan Maunatin, 2012).

\section{Kurva Pertumbuahan L.plantarum}

Pembuatan kurva pertumbuhan $L$. plantarum DJ3 dilakukan dengan menggunakan shaker incubator pada suhu $30^{\circ} \mathrm{C}$ kecepatan $100 \mathrm{rpm}$ selama 24 jam. Kurva pertumbuhan yang dilakukan pada penelitian ini hanya sampai pada fase logaritmik.

Pengamatan adanya pertumbuhan sel dilakukan dengan melihat terjadinya kekeruhan pada medium tumbuh BAL yaitu MRS broth dan setiap 3 jam mengukur nilai Optical Density (OD) pada panjang gelombang $600 \mathrm{~nm}$ dengan pengenceran $10^{-1}$.

Gambar 2 menunjukkan bahwa kurva pertumbuhan L.plantarum DJ3 ditandai dengan meningkatnya nilai OD medium sejalan dengan meningkatnya lama waktu inkubasi. Tahapan fase lambat (Lag Phase) pada pertumbuhan L.plantarum DJ3 tidak terlihat sehingga fase adaptasi terjadi sebelum jam ke 3.

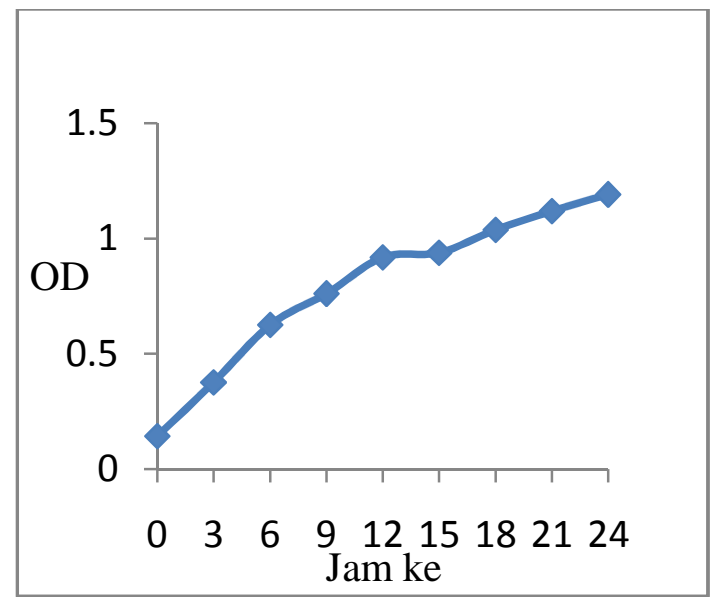

Gambar 2. Kurva Pertumbuhan L. Plantarum DJ3

Pada fase lambat ini populasi L.plantarum DJ3belum mengalami pertumbuhan yang berarti, dikarenakan baru saja menyesuaikan dalam medium yang baru. Menurut Madigan et al.,(2000) dalam Astuti dan Rahmawati (2010), hal tersebut menyebabkan sel belum dapat melakukan reproduksi atau pembelahan, tetapi masih beradaptasi dengan medium atau lingkungan barunya. Fase lambat ini memungkinkan terjadinya penambahan ukuran sel, tetapi bukan pada jumlah selnyakarena pada jam awal inkubasi ini densitas belum meningkat secara nyata. Fase logaritmik (Exponential Phase) ditandai dengan bertambahnya populasi secara signifikan. Jumlah sel meningkat setelah jam ke-3 sampai jam ke-24. Sebelum perlakuan produksi bakteriosin, inokulum yang dipakai berumur 18 jam, karena pada jam ke18 L.plantarum DJ3 pada fase logaritmik, 
sehingga telah siap dipakai sebagai inokulum. Sedangkan pada produksi bakteriosin fermentasi dilakukan selama $24 \mathrm{jam}$. Menurut Djide dan Sartini (2008), umumnya bakteri asam laktat menghasilkan senyawa metabolit primer seperti asam laktat, asam asetat, hidrogen peroksida dan bakteriosin pada fase logaritmik dan fase stasioner. Fardiaz (1988), metabolit primer seperti asam laktat, asam asetat dan hidrogen peroksida berfungsi sebagai antibakteri. Menurut Sarkono et al., (2006), Giraud et al., (1994) dalam Harmayani et al., (2009), bakteri asam laktat memproduksi metabolit primer pada akhir fase logaritmik jam ke-18 sampai jam ke-24. Yuliana (2007), menyatakan bahwa untuk bakteri asam laktat fase logaritmik biasanya dicapai pada inkubasi $18-24$ jam tergantung media dan jenis BAL.

\section{Produksi Bakteriosin oleh Lactobacillus plantarum DJ3}

Penelitian tahap I melakukan produksi bakteriosin yang dihasilkan oleh L.plantarum DJ3 dan dilakukan uji aktivitas bakteriosin tersebut terhadap bakteri patogen. Produksi bakteriosin secara fermentasi pada penelitian ini dilakukan dengan menggunakan shaker incubator pada suhu $30^{\circ} \mathrm{C}$ kecepatan $100 \mathrm{rpm}$ selama 24 jam. Produksi bakteriosin mencapai maksimal pada pertengahan fase logaritmik sampai awal fase stasioner. Umumnya aktivitas bakteriosin setelah memasuki fase stasioner mengalami penurunan karena meningkatnya produksi enzim-enzim proteolitik yang akan mereduksi bakteriosin (Jimenez, 1993). Adapun media produksi bakteriosin pada penelitian ini menggunakan media MRS broth yang telah ditambahkan inducer yaitu yeast extract sebanyak $2 \%$ (b/v). Penelitian yang dilakukan oleh Ogunbanwo, et al., (2003) menunjukkan bahwa penambahan yeast extract sebanyak $2 \%$ pada media MRS broth dapat meningkatkan aktivitas bakteriosin sekitar dua kali. Ekstrak kasar bakteriosin yang dihasilkan oleh L.plantarumDJ3 dapat dilihat pada Gambar 3.

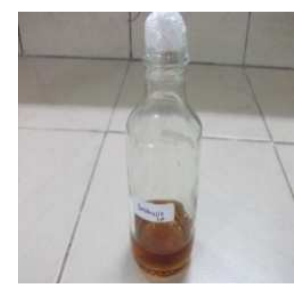

Gambar 3. Ektrak Kasar Bakteriosin
Adanya aktivitas bakteriosin dari filtrat hasil fermentasi L.plantarum DJ3 dapat diketahui dengan melakukan uji aktivitas anti mikroba dari bakteriosin menggunakan metode difusi cakram dengan bakteri uji Eschericia coli dan Staphylococcus aureus kemudian setelah inkubasi pada suhu ruang selama 24 jam maka zona penghambatan yang terbentuk diamati. Bakteri uji yang digunakan dalam penelitian ini mewakili bakteri gram positif yaitu Staphylococcus aureus dan bakteri gram negatif yaitu Eschericia coli, agar dapat diketahui keefektifan ekstrak kasar bakteriosin dalam menghambat kedua jenis bakteri patogen tersebut. Zona bening yang terbentuk di sekitar kertas cakram menunjukkan bahwa bakteri uji tidak dapat tumbuh. Adapun diameter zona penghambatan bakteriosin terhadap bakteri patogen disajikan pada Tabel 1.

Tabel 1. Zona Penghambat Bakteriosin Terhadap Bakteri Patogen

\begin{tabular}{cccccc}
\hline Jenis & Bakt & \multicolumn{2}{c}{$\begin{array}{c}\text { Diameter zona } \\
\text { BAL }\end{array}$} & $\begin{array}{c}\text { eri } \\
\text { pato }\end{array}$ & \multicolumn{2}{c}{ Rambat (mm) } & Ra \\
\cline { 3 - 5 } & gen & Ulan & Ulan & Ulan & Ra 1 \\
gan 2 & gan 3 & ta \\
\hline L.plant & $\begin{array}{c}\text { E.col } \\
\text { arum }\end{array}$ & 4 & 4 & 4 & 4 \\
& $i$ & & & & \\
\cline { 2 - 5 } & $\begin{array}{c}\text { S.aur } \\
\text { eus }\end{array}$ & 5 & 6 & 5 & 5.3 \\
& & & & 3 \\
\hline
\end{tabular}

Tabel 1 menunjukkan bahwa L.plantarum mempunyai aktivitas penghambatan bakteriosin lebih kuat terhadap bakteri S.aureus daripada E coli yaitu masingmasing penghambatan $4 \mathrm{~mm}$ untuk E.coli dan $5.33 \mathrm{~mm}$ untuk S.aureus. Hal ini sesuai dengan penelitian yang telah dilakukan Jin, et al., (1996) bahwa Lactobacillus menunjukkan sifat antibakterial dari bakteriosin yang lebih kuat terhadap bakteri-bakteri gram positif (Staphylococcus aureus dan Listeria monocytogens) daripada bakteri-bakteri gram negatif (Salmonella typhi dan E.coli).

Dinding sel bakteri merupakan kerangka kaku di luar membran sel bakteri. Membran sel bakteri membungkus suatu massa yang bertekanan tinggi mencapai 20 atm karena mengandung metabolit yang tekanannya lebih tinggi dari tekanan sekitar sel. Bila tidak ada dinding sel maka membran sel tidak mampu untuk menahan tekanan osmotik di dalam sel 
bakteri sehingga sel akan pecah (Januarsyah, 2007). Dinding sel bakteri gram negatif lebih kompleks dan berlapis serta tidak mengandung asam teikat sebagai salah satu reseptor bakteriosin (Bhunia et al., 1991) sehingga akan lebih resisten terhadap bakteriosin. Selain itu adanya perlindungan membran luar yang membentuk lapisan terluar dari selubung sel akan berfungsi sebagai penghalang yang efesien melawan larutan hidrofobik tertentu dan makromolekul (Olasupo et al., 2003).

Beberapa penelitian mendapatkan hasil yang berbeda bahwa beberapa jenis bakteriosin menunjukkan spektrum yang lebih luas. Ray (1992) mengemukakan bahwa nisin dan pediosin AcH memiliki aktivitas bakterisidal terhadap bakteri gram positif dan gram negatif. Bakteriosin lain yang dilaporkan aktif melawan bakteri gram negatif terutama E.coli dan S.typhimurium diantaranya bakteriosin dari Lactococcus lactis KSA2386 dan lacticin NK24 (Todorov dan Dicks, 2004), bakteriosin dari Lactobacillus brevis OG1 (Ogunbanwo et al., 2003), bakteriosin dari Leuconostoc yang diisolasi dari produk daging kemas vakum (Budde et al., 2003), serta bakteriosin yang diproduksi dari Lactobacillus plantarum hasil isolasi dari molasses (Todorov dan Diks, 2005).

Aktivitas bakteriosin yang dihasilkan oleh L.plantarum DJ3 dalam penelitian ini lebih kecil jika dibandingkan dengan penelitian yang telah dilakukan oleh Ogunbanwo, et al., (2003) yang melaporkan bahwa bakteriosin yang dihasilkan oleh L.plantarum F1 mampu menghambat E.coli dan S.aureus dengan zona penghambatan masing-masing sebesar $8 \mathrm{~mm}$, sedangkan bakteriosin yang dihasilkan oleh L.brevis OG1 mampu menghambat E.coli dan S.aureus dengan zona penghambatan masingmasing sebesar $6 \mathrm{~mm}$ dan $5 \mathrm{~mm}$. Sehingga bakteriosin yang diperoleh dalam penelitian ini mempunyai kemampuan yang hampir sama dengan bakteriosin yang dihasilkan oleh L.brevis OG1 dalam menghambat bakteri patogen yaitu E.coli dan S.aureus.

Zona penghambatan bakteriosin terhadap E.coli dan S.aureus dapat dilihat pada Gambar 4 dan 5. Adapun jumlah bakteri patogen yang digunakan dalam penelitian ini mempunyai OD sebesar 0.3 atau setara dengan $10^{8} \mathrm{cfu} / \mathrm{ml}$.

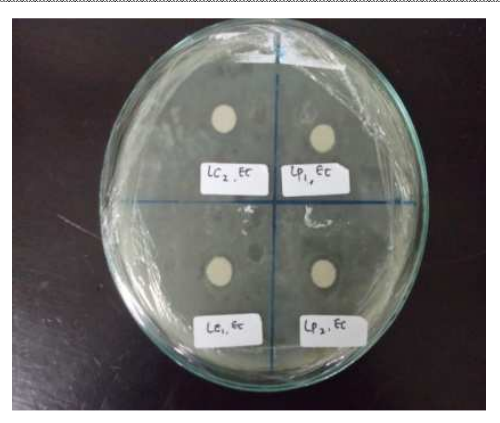

Gambar 4. Penghambatan Bakteriosin Terhadap E.coli

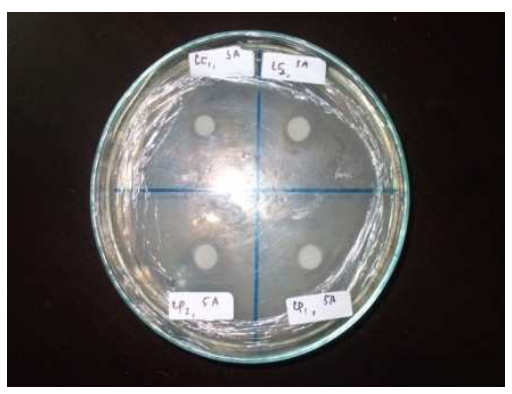

Gambar 5. Penghambatan Bakteriosin Terhadap S.aureus

\section{Aplikasi Bakteriosin Sebagai Pengawet Daging Sapi}

Pemakaian bakteriosin komersial sebagai biopreservatif sudah dilakukan di beberapa negara dan diaplikasikan pada beberapa jenis makanan. Beberapagalur bakteri asam laktat (BAL) dapat menghasilkan senyawa protein yang disebut bakteriosin, dan bersifat bakterisidal terhadap bakteri gram positif dan gram negatif (Tahara et al., 1996). Bakteriosin dapat diproduksi oleh Lactococcus, Lactobacillus dan Pediococcus, misalnya nisin diproduksi oleh Lactococcus lactis, pediosin AcH dihasilkan Pediococcus acidilactic.

Beberapa kelebihan bakteriosin sehingga potensial digunakan sebagai biopreservatif yaitu (Cleveland et al., 2001) :

1. Bukan bahan toksik dan mudah mengalami degradasi oleh enzim proteolitik karena merupakan senyawa protein;

2. Tidak membahayakan mikroflora usus karena mudah dicerna oleh enzim saluranpencernaan;

3. Dapat mengurangi penggunaan bahan kimia sebagai pengawet pangan;

4. Penggunaannya fleksibel; dan

5. Stabil terhadap $\mathrm{pH}$ dan suhu yang cukup luas sehingga tahan terhadap proses 
pengolahan yang melibatkan asam dan basa, serta kondisi panas dan dingin

Menurut Ray (1996), beberapa bakteriosin BAL yang digunakan sebagai biopreservatif dalam berbagai produk makanan antara lain adalah bakteriosin yang dihasilkan oleh Lactobacillus sp.

Bakteriosin yang dihasilkannya memiliki spektrum yang luas sebagai pengawet makanan dan mampu melawan bakteri gram negatif patogen. Lactobacillus $s p$. dapat ditemukan di dalam daging, produk daging, susu, saluran pencernaan, dan makanan yang difermentasi secara terkontrol. Penelitian ini menggunakan ekstrak kasar bakteriosin hasil fermentasi dari Lactobacillus plantarum DJ3.

Daging mudah rusak oleh kontaminasi mikroba, untuk mencegahnya dapat dilakukan dengan pemberian pengawet alami yaitu bakteriosin yang dihasilkan oleh L.plantarum DJ3. Bakteriosin mampu menghambat bakteri pathogen dan pembusuk dengan efektif. Pemberian pengawet bakteriosin dalam penelitian ini dilakukan dengan cara perendaman daging dalam ekstrak kasar bakteriosin selama 30 menit, selanjutnya daging yang telah diberi pengawet bakteriosin disimpan pada suhu ruang.

Lama penyimpanan daging sampai 12 jam dan pada jam ke 8 dan jam ke 12 jumlah bakteri yang tumbuh pada daging diamati dengan Total Plate Count (TPC) untuk mengetahui tingkat kerusakan daging. Jumlah bakteri yang ada pada daging dengan pemberian ekstrak kasar bakteriosin dan tanpa ekstrak kasar bakteriosin pada penyimpanan suhu ruang disajikan pada Tabel 2.

Tabel 2. Jumlah Bakteri pada Daging Setelah Penyimpanan

\begin{tabular}{cccccc}
\hline Perlakuan & $\begin{array}{c}\text { Lama Penyimpanan } \\
\text { (Jam) }\end{array}$ & \multicolumn{3}{c}{ Jumlah Bakteri (Cfu/g) } & Rata-rata \\
\cline { 2 - 5 } & 8 & $\mathbf{1}$ & $\mathbf{2}$ & $\mathbf{3}$ & \\
\hline Pemberian & 12 & $1.4 \times 10^{8}$ & $2.1 \times 10^{8}$ & $3.1 \times 10^{7}$ & $1.3 \times 10^{8}$ \\
Bakteriosin & 8 & $5.2 \times 10^{9}$ & $1 \times 10^{9}$ & $8.1 \times 10^{7}$ & $2 \times 10^{9}$ \\
\hline Tanpa & 12 & $3.7 \times 10^{8}$ & $4.9 \times 10^{8}$ & $2.5 \times 10^{8}$ & $3.7 \times 10^{8}$ \\
\cline { 2 - 5 } $\begin{array}{c}\text { Bakteriosin } \\
\text { (Kontrol) }\end{array}$ & $2 \times 10^{11}$ & $2.2 \times 10^{11}$ & $1.5 \times 10^{10}$ & $1.5 \times 10^{11}$ \\
\hline
\end{tabular}

Jumlah awal bakteri pada daging yang digunakan dalam penelitian ini cukuptinggi yaitu $2.3 \times 10^{5} \mathrm{Cfu} / \mathrm{g}$. Hal ini bisa disebabkan karena daging yang digunakan dalam penelitian ini dibeli dari pedagang di pasar yang diperlakukan pada suhu ruang (bukan suhu rendah) sehingga secara internal daging akan terkontaminasi jika tidak didinginkan setelah penyembelihan.

Jumlah dan jenis mikroorganisme yang mencemari daging ditentukan oleh tingkat pengendalian higienis yang dilaksanakan selama penanganan, diawali saat penyembelihan ternak dan pembersihan karkas hingga sampai ke konsumen. Pertumbuhan mikroorganisme berhubungan erat dengan kualitas daging segar. Peningkatan jumlah mikroorganisme pembusuk berpengaruh terhadap daya tahan atau masa simpan daging.

Penelitian ini menunjukkan bahwa pada semua perlakuan lama penyimpanan dengan pemberian ekstrakkasar bakteriosin lebih mampu menghambat pertumbuhan bakteri pada daging jika dibandingkan dengan tanpa pemberian ekstrak kasar bakteriosin (kontrol) dimana pertumbuhan bakteri daging lebih cepat. Penyimpanan daging selama 8 jam menunjukkan jumlah bakteri yang tumbuh adalah $1.3 \times 10^{8} \mathrm{cfu} / \mathrm{g}$ yaitu mengalami kenaikan sebesar $3 \log$ dari jumlah awal bakteri daging, sedangkan pada kontrol jumlah bakteri yang tumbuh adalah $3.7 \times 10^{8} \mathrm{cfu} / \mathrm{g}$ yaitu mengalami kenaikan sebesar 3 log.

Penyimpanan selama 8 jam belum menunjukkan bau busuk untuk perlakuan dengan penambahan ekstrakkasar bakteriosin, tetapi untuk daging yang tidak diberi ekstrak kasar bakteriosin sudah menunjukkan adanya bau busuk karena jumlah bakterinya lebih banyak. Menurut Russel (2001) bau busuk dan lendir timbul ketika jumlah bakteri mencapai $1 \times 10^{8} \mathrm{cfu} / \mathrm{cm}^{2}$, sedangkan penelitian lain menyebutkan bahwa bau busuk timbul ketika jumlah bakteri mencapai $1.2 \times 10^{6} \mathrm{cfu} / \mathrm{cm}^{2}$ dan lendir timbul ketika bakteri berjumlah sekitar $3.2 \times 10^{7}-1 \times 10^{9} \mathrm{cfu} / \mathrm{cm}^{2}$. Bau busuk karena produksi hidrogen sulfida $\left(\mathrm{H}_{2} \mathrm{~S}\right), \mathrm{NH}_{3}$ dan merkaptan yang merupakan bahan utama 
penyebab bau busuk akibat metabolisme protein oleh mikroorganisme. Bakteri penyebab bau busuk diantaranya Pseudomonas, Shewanella, Serratia, dan Brochothrix (Ray, 2004). Lendir umumnya disebabkan oleh bakteri berkapsul (Alcamo, 1983), di antaranya Pseudomonas dan Alcaligenes (Frazier dan Westhoff, 1988). Daging dengan kontaminan $10^{5} \mathrm{cfu} / \mathrm{cm}^{2}$ akan menjadi busuk dalam 6 hari apabila disimpan pada suhu $5^{\circ} \mathrm{C}$ dan daging dengan kontaminan $10^{3} \mathrm{cfu} / \mathrm{cm}^{2}$ tidak akan menjadi busuk selama 10-11 hari penyimpanan pada suhu $5^{0} \mathrm{C}$ (Suyasa, 2002). Jumlah awal bakteri pada daging yang digunakan dalam penelitian yaitu $10^{5} \mathrm{Cfu} / \mathrm{g}$ dan perlakuan penyimpanan daging dilakukan pada suhu ruang sehingga sangat memungkinkan untuk menyebabkan kerusakan daging lebih cepat.

Total bakteri daging yang diberi ekstrak kasar bakteriosin pada jam ke 12 adalah $2 \times 10^{9}$ cfu/g yaitu mengalami kenaikan sebesar $4 \log$ dari jumlah awal bakteri daging dan daging juga mulai berbau busuk, sedangkan pada kontrol jumlah bakteri adalah $1.5 \times 10^{11} \mathrm{cfu} / \mathrm{g}$ yaitu mengalami kenaikan sebesar $6 \log$ dan bau busuk bertambah menyengat dibandingkan dengan penyimpanan selama 8 jam. Jumlah bakteri yang lebih rendah pada daging dengan perlakuan pemberian ekstrak kasar bakteriosin bisa terjadi karena bakteriosin bersifat melisiskan sel bakteri sehingga menyebabkan proses kematian pada sel yang sensitif terhadap bakteriosin (Gonzales et al., 1996). Hal ini mampu menghasilkan lingkungan yang tidak menguntungkan bagi bakteri.

Secara umum peningkatan jumlah populasi bakteri sejalan dengan lamanya waktu penyimpanan daging disebabkan oleh adanya pertumbuhan dan perkembangan bakteri pada daging dengan kondisi lingkungan yang mendukung. Daging merupakan media yang baik untuk pertumbuhan dan perkembangan mikroorganisme termasuk mikroorganisme pembusuk, hal ini karena : (1) mempunyai kadar air yang tinggi sekitar $68-75 \%$ (2) kaya akan zat yang mengandung nitrogen dengan kompleksitasnya yang berbeda, (3) mengandung sejumlah karbohidrat yang dapat difermentasikan, (4) kaya akan mineral dan kelengkapan faktor untuk pertumbuhan mikroorganisme, (5) mempunyai $\mathrm{pH}$ yang menguntungkan untuk sejumlah mikroorganisme (Soeparno ,1994).

\section{KESIMPULAN}

Ekstrak kasar bakteriosin yang dihasilkan oleh Lactobacillus plantarum DJ3mampu menghambat pertumbuhan E. coli dan $S$. aureus masing-masing sebesar $4 \mathrm{~mm}$ dan $5.33 \mathrm{~mm}$.

Ekstrak kasar bakteriosin dari Lactobacillus plantarum DJ3mampu menghambat pertumbuhan bakteri daging. Bakteri pada daging selama penyimpanan 8 jam adalah $1.3 \times 10^{8} \mathrm{cfu} / \mathrm{g}$ dengan pemberian bakteriosin dan $3.7 \times 10^{8}$ tanpa pemberian bakteriosin. Sedangkan jumlah bakteri pada penyimpanan daging salama 12 jam adalah $2 \times 10^{9} \mathrm{cfu} / \mathrm{g}$ dengan pemberian bakteriosin dan $1.5 \times 10^{11}$ tanpa pemberian bakteriosin.

\section{SARAN}

1. Sebaiknya sampel daging sapi yang digunakan diambil dari RPH

2. Perlu dilakukan penelitian lebih lanjut tentang aplikasi pengawetan daging menggunakan ekstrak kasar bakteriosin dari Lactobacillus plantarum DJ3 dengan penyimpanan pada suhu rendah.

\section{DAFTAR PUSTAKA}

Alcamo, I. E. 1983. Fundamentals of Microbiology. Addison-Wesley Publishing Company, London.

Ammor S., G. Tauveron, E. Dufour, and I. Chevallier. 2006. Antibacterial activity of lactic acid bacteria against spoilage and pathogenic bacteria isolated from the same meat smallscalefascility : 1Screening and characterization of the antibacterial compounds. Food

Bhunia, A. K., M. C. Johnson, B. Ray, and N. Kalchaanand. 1991. Mode of action of pediocin AcH from Pediococcus acidilactici $H$ on sensitive bacteria strains. J. Appl. Bacteriol. 70 : 1-25.

Budde, B. B. and M. Jakobsen. 2000. Realtime Measurements of The Interaction Between Single Cells of Listeria monocytogenes and Nisin on A Solid Surface. J. Appl. Environ. Microbiol. 66 (8) : 3586-3591.

Cleveland, J., J.T. Montville, I.F.Nes and M.L. Chikindas. 2001. Bacteriocin: safe, natural antimicrobils for food preservation. International Journal of Food Microbiology 71:1-20. 
Frazier, W. C. and D. C. Westhoff. 1988. Food Microbiology. 4th Edition. McGraw-Hill Book Company, Singapore.

Gonzales, B. E., F. Glaasker, F. R. S. Kunji. A. J. M. Driessen, J. E. Suarez, and W. N. Konings. 1996. Bactericidal mode of action of Plantaricin S. J. Appl. Environ. Microbiol. 62:2701-2709.

Januarsyah, T., 2007, Kajian Aktivitas Hambat Bakteriosin dari Bakteri Asam Laktat Galur SCG 1223. Skripsi, Fakultas Teknologi Pertanian, IPB, Bogor.

Lawrie, R.A., 2003, Ilmu Daging, Edisi kelima, Penerjemah Aminuddin P., Penerbit Universitas Indonesia, Jakarta.

Loekman S, Maamoen A, Ridwan S, Suparmi, Edison. 1991. Pengaruh Pengemasan terhadap Mutu Ikan Baung(Macrones sp)Asap. Jurnal Penelitian, Pusat Penelitian Universitas Riau.

Madigan MT, Martinko JM (2006). Brock: Biology of Microorganism. Pearson Education International. ISBN 0-13196893-9.Page.375-377

Mataragas, M., E.H. Drosinos, and J. Metaxopoulos. 2003. Antagonistic activity of lactic acid bacteria against Listeria monocytogenes in sliced cooked cured pork shoulder stored under vacuum or modified atmosphere at $4 \pm 2^{\circ} \mathrm{C}$. Food Microbiology 20: 259265.

Muwakhid dan Maunatin, 2012, Uji Kemampuan BAL Selulolitik Asal Usus Itik Petelur sebagai Probiotik. Proceeding Greentech 3. UIN MALIKI Malang

Nugroho, D.A. dan Rahayu, E.S. 2003. Ekstraksi dan Karakterisasi Bakteriosin yang Dihasilkan oleh Leuconostoc mesenteroides SM 22. J.Teknol.dan Industri Pangan, Vol XIV (3)

Ogunbanwo, S. T., A. I. Sanni, and A. A. Onilude. 2003. Influence of cultural conditions on the production of bacteriocin by Lactobacilus brevis OGI. Afric. J. Biotechnol. 2 (7) : 179-184.

Olasupo, N. A., D.J. Fitzgerald, M.J. Gasson, and A. Narbad. 2003. Activity of natural antimicrobial compounds against Escherichia coli and Salmonella enterica serovar typhimurium. Lett. Appl. Microbiol. 36 : 448-451.

Ray, B. 1996. Fundamental Food Microbiology. CRC Press, London.
Ray, B. 2004. Fundamental Food Microbiology. 3rd Edition. CRC Press, London.

Razak, A.R, Patong, A.R, Harlim, T., Djide, M.N., Haslia dan Mahdalia. 2009. Produksi Senyawa Bakteriosin Secara Fermentasi menggunakan isolat BAL Enterrrococcus faecium DU55 dari Dangke. J.Indonesia Chemica Acta Vol 2 (2) : ISSN 2085-014X

Russel, S. M., 2001. Spoilage bacteria associated with poultry. In : A. R. Sams (Editor). Poultry Meat Processing. CRC Press, New York.

Soeparno. 1998, Ilmu dan Teknologi Daging. Gadjah Mada University Press, Yogyakarta.

Suyasa, I. N. 2002. Penambahan asam asetat dan asam laktat serta pengaruhnya terhadap kualitas daging sapi. Tesis. Program Pascasarjana Institut Pertanian Bogor, Bogor.

Tahara, T., M. Oshimura, C. Umezawa and K. Kanatani. 1996. Isolation partial characterization and mode of action acidocin J1132, a two-compound bacteriocin produced by Lactobacillus acidophilus JCM 1132. Appl. Environ. Microbiol. 62:892-897.

Todorov, S. D. and L. M. T. Dicks. 2005. Lactobacillus plantarum isolated from molasses produces bacteriocins active against Gram-negative bacteria. J. Enz. Microb. Technol. 36 : 318-326.

Usmiati, S. dan Marwati, T. 2007. Seleksi dan Optimasi Proses Produksi Bakteriosin dari Lactobacillus sp. J. Pascapanen 4(1) : 27-37

Usmiati, S. 2009, Penggunaan Bakteriosin untuk mempertahankan Kesegaran Daging Ayam. Balai Besar Penelitian dan Pengembangan Pascapanen Pertanian. Bogor

Usmiati, S. 2010. Pengawetan Daging Segar dan Olahan.Balai Besar Penelitian dan Pengembangan Pascapanen Pertanian. Bogor 
